See discussions, stats, and author profiles for this publication at:

http://www.researchgate.net/publication/273697079

\title{
Entrepreneurship, Leadership, and the Value of Feminist Approaches to Understanding Them
}

ARTICLE in JOURNAL OF SMALL BUSINESS MANAGEMENT · JULY 2015

Impact Factor: $1.39 \cdot$ DOI: 10.1111/jsbm.12178

CITATION

1

3 AUTHORS, INCLUDING:

Laura Galloway

Heriot-Watt University

49 PUBLICATIONS 349 CITATIONS

SEE PROFILE

\section{Isla Kapasi}

Edinburgh Napier University

9 PUBLICATIONS 1 CITATION

SEE PROFILE
READS

51 


\section{Entrepreneurship, Leadership, and the Value of Feminist Approaches to Understanding Them by Laura Galloway, Isla Kapasi, and Katherine Sang}

Entrepreneurship research principally focuses on business growth. This focus valorizes the masculine and marginalizes other interpretations. Consequently, entrepreneurship is restricted to a phenomenon that is rare in the diverse business world. The leadership literature proposes that entrepreneurship may not be as masculine as we assume anyway. Our understanding of entrepreneurship needs development at the conceptual level. We argue that performativity, as described in feminist theory, can contribute to how we interpret entrepreneurship and that this might inform both the entrepreneurship and leadership literatures to afford us better understanding of what we might mean by "entrepreneurial leadership."

\section{Introduction}

Entrepreneurship is often defined as business start-up activity or as growth within existing firms (e.g., Drucker 1986). A third definition proposes synonymity with business ownership (e.g., Xavier et al. 2013). These various definitions make the analysis of entrepreneurship challenging. The emerging expression "entrepreneurial leadership" is correspondingly challenging. On the one hand, it implies leadership that will prompt commercial growth, whereas on the other hand, firms owned by those who do not seek to grow are yet still led. If we ignore the evidence that most independent businesses do not grow (Ahl 2006), and stick with the idea that entrepreneurship requires financial growth, we find that modern leadership theories are reasonably compatible with this.

Most modern theories of leadership identify that value-adding is best achieved through visioning and conducting leadership in such a way as to promote "buy in" from followers (e.g., Avolio and Bass 2002). This resonates well with received wisdom about entrepreneurship, particularly with reference to entrepreneurial vision, charismatic communication of that vision, and the ability to assemble and manage resources, including knowledge and other human resources (e.g., Mintzberg, Ahlstrand, and Lampel 1998; Thompson 1999). This received wisdom has, however, been subject to criticism in terms of it being culturally biased and gendered; it has been criticized for representing a Western idealization of business creation and success, viewed from a male normative perspective (Ogbor 2000; Williams and Nadin 2013). Conceptualizations of leadership have been similarly accused (e.g., Eagly 2005). Consequently, we argue in this paper that ideas about entrepreneurship and leadership, and "entrepreneurial

Laura Galloway is professor of Business \& Enterprise in the School of Management \& Languages at the Heriot-Watt University.

Isla Kapasi is graduate teaching assistant in the School of Management \& Languages at the Heriot-Watt University.

Katherine Sang is associate professor in the School of Management \& Languages at the Heriot-Watt University.

Address correspondence to: Laura Galloway, School of Management \& Languages, Heriot-Watt University, Riccarton, Edinburgh EH14 4AS, UK. E-mail: 1.galloway@hw.ac.uk. 
leadership" specifically, require much greater inspection.

This paper seeks to unpack conceptualizations of entrepreneurship and leadership, with specific reference to the limiting effect that currently gendered interpretations have on our understanding of these important social and economic phenomena. Acknowledging the growing body of work calling for process interpretations of entrepreneurship, we propose that the performativity proposition within feminist theory in particular would develop understanding of both entrepreneurship and leadership. The paper contributes by adopting the proposition that taking a performativity perspective and considering the enactment of entrepreneurship will further develop study in this area revealing a richer, more nuanced understanding of these complex phenomena as well as the roles of gender.

We begin with a consideration of the extant literature on entrepreneurship highlighting the gendered (masculinized) nature of the construct. We then move to a discussion of the "entrepreneurial leader," exploring current conceptualizations of this term. Following these, we present a summary of alternative perspectives on both entrepreneurship and leadership that challenge their conceptualizations as fixed objective phenomena. We conclude by suggesting the potential for feminist theory in particular to contribute to our understanding of entrepreneurship and leadership, and the potential of this to open avenues for further work.

\section{Entrepreneurship and Gender}

Moroz and Hindle (2012) find that there is nothing that is distinctly entrepreneurial in the business world, nor is there anything always entrepreneurial. Despite this, the idea that entrepreneurship involves commercial growth is a long-established interpretation (Drucker 1986; Fris, Karlsson, and Paulsson 2005; Mintzberg, Ahlstrand, and Lampel 1998). Of course, there are other interpretations of entrepreneurship. Classic Schumpeterian interpretations, for example, prioritize innovation (e.g., Florida 2003; Salaman and Storey 2002). Elsewhere, entrepreneurship is considered in terms of its potential to foster greater social equality in the face of structural (and other) inequalities in the employment market (e.g., Calás, Smircich, and Bourne 2009; Ram et al. 2000; Smith and Air 2012). But these as units of analysis are rare, relative to the canon of studies that use the pursuit of growth at the firm level as the feature that defines entrepreneurship. In her meta-analysis, Ahl (2006) identifies that financial growth, with its inferred and expected economic contribution, is the single most common rationale for studies of entrepreneurship and that entrepreneurship research is thus legitimized in the business and economics literatures. However, the enactment of entrepreneurship as growth-oriented behavior is culturally masculinized, specifically tied to particular forms of masculinity. Bem (1981) proposed a Masculinity and Femininity Index from analyses of expressions used to describe these as binary constructions. Within this framework, certain traits are deemed "masculine" or "feminine" with "acts like a leader" attributed to masculinity. Noting that the performance of masculinities and femininities is not limited to those with male and female bodies (Butler 1990; Sang, Dainty, and Ison 2014), it is important not to essentialize gender. Despite this, Bem's Index has been validated by Holt and Ellis (1998) in terms of confirming the applicability of all but two (loyal and childlike) of the terms used to describe perceptions of gender roles.

Related specifically to entrepreneurship, Ahl (2006) uses Bem's Index to identify that it is consistently positioned throughout the literature as a masculinized activity: She found correlation with masculinity and none with femininity. This is reflected throughout the entrepreneurship literature; various authors have identified the normative and masculinized approach most often taken in studies of entrepreneurship (Díaz-García and Welter 2013; Petterson 2004; Steyaert 2007). Further, if entrepreneurship requires the pursuit of growth, then "successful" entrepreneurship must be defined as business activity that has resulted in growth. But this overwhelming focus on firm growth does not reflect most business activity as it occurs in reality. Not only does it ignore the diversity of business in the real world (e.g., Hamilton 2006; Howarth, Tempest, and Coupland 2005; Morris et al. 2006), but it also does not correspond with the majority of business experience; most businesses are not growth oriented (Ahl 2006; Levie and Lichtenstein 2010). Further, entrepreneurship understood as an individualized, growthoriented activity marginalizes other ways in which entrepreneurship is enacted (Ahl and 
Marlow 2012; Petterson 2004). It also limits entrepreneurship as a concept by limiting constructions of "the entrepreneur." Despite the fact that most businesses are created and operated by partners or teams, and in fact in most countries the most common business model is family owned and operated (Drucker 1995; Nordqvist and Melin 2010), "the entrepreneur" prevails as a construction. This entrepreneur has become normalized as male; he is the man who creates a growth firm or who leads an organization to financial growth (Franco and Matos 2013). However, Gartner (1989) asserted a quarter of a century ago that asking "who is the entrepreneur?" is the wrong question. Since then, other authors such as Campbell (2004) and Calás, Smircich, and Bourne (2009) have continued to criticize focus on "the entrepreneur" as an objective truth. Despite these, notions of "the entrepreneur" prevail in the extant literature, and in terms of leadership specifically, a new conceptualization is developing: the "entrepreneurial leader"; it is to this that we now turn.

\section{The Entrepreneurial Leader}

In terms of defining entrepreneurial leadership, Gupta, Macmillan, and Surie (2004, p. 243) maintain that it is "leadership capable of sustaining innovation and adaptation in high velocity and uncertain environments," and it is key to "continuously creating and appropriating value in a firm." Gupta et al. further assert that the two main functions of the entrepreneurial leader are to have and communicate vision in terms of growth outcomes, and to engage followers and other stakeholders into performing to achieve the realization of this vision. These principles are echoed throughout the modern leadership literature.

Modern leadership theory is based on the general principles of contingency and situation (e.g., Blanchard, Zigarmi, and Zigarmi 1985; Fiedler 1967, respectively) which propose flexibility of leadership style contingent on the circumstances, environment, task, and followers. To achieve value-adding in the commercial world requires vision of a leader and engagement of followers. As such, most leadership in commercial organizations is positioned somewhere on the transactional to transformational leadership continuum, according to Avolio (1999). Whereas transactional leadership involves reward and reward withdrawal (or punishment) (Bass 1998), transformational leadership involves communicating vision, and inspiring and engaging followers (Avolio and Bass 2002; Bass 1998; Bass and Riggio 2006). Transformational leadership is made up of four critical features: idealized influence, where the leader becomes a role model for followers; inspirational motivation, where followers are inspired by the leader; intellectual stimulation, where followers are challenged and motivated; and individual consideration, where the ambitions and interests of followers are supported and engaged by the leader (Avolio and Bass 2002). Transformational leadership is thus about having and communicating vision, and having followers engage and participate in realizing it, as per Gupta et al.'s (2004) requirements of entrepreneurial leadership. Other theoretical and empirically observed approaches to leadership identify these critical elements also. For example, Geoghegan and Dulewicz (2008) describe value-adding leadership as a combination of transformational style and specific traits. Similarly, charismatic leadership (Shamir, House, and Arthur 1993) requires idealized behavior and the facilitation of buy-in from followers via consideration of individuals. Likewise, Ryan and Deci (2003) advocate authentic leadership for value-adding activity, where leaders are demonstrably engaged in the pursuit of a personalized vision.

So, theoretically at least, there are clear parallels in the leadership and entrepreneurship bodies of knowledge. Throughout the literature, these infer the requirement of emotional intelligence, an awareness of the emotional needs of others and the social skills to navigate them (Goleman 1998). Extrapolating from the descriptions in Goleman (2000), Nixon, Harrington, and Parker (2012) summarize emotional intelligence as including self-awareness, self-regulation, motivation, empathy, and social skills, as illustrated in Table 1.

If emotional intelligence is critical to effective value-adding leadership, and if this is the type of leadership most appropriate in the growth-focused entrepreneurial context, then logic dictates that entrepreneurial leadership requires authentic leadership and emotional intelligence. Yet the inclusion of emotion as a focus of study is largely absent in the entrepreneurship literature, despite its intuitive importance when applied to the humans who create, develop, and lead firms (Calás, Smircich, and Bourne 2009; Campbell 2004) (though some interesting studies, such as Cardon et al. (2012), 


\section{Table 1}

Goleman's Five Features of Emotional Intelligence
Component

Definition
Self-Awareness

The ability to recognize and understand your moods, emotions, and drives, as well as their effect on others

Self-Regulation The ability to control or redirect disruptive impulses and moods; the ability to suspend judgment and think before acting

Motivation Exhibiting a passion to work for reasons outside money or status; a drive to pursue goals with energy and persistence

Empathy

Social Skill
The ability to understand the emotional makeup of others; skills in treating others according to their emotional reactions

Capable of managing relationships and building networks; able to find common ground and build a relationship
Adapted From Nixon, Harrington, and Parker 2012 (p. 210).

are beginning to emerge). Further, if we apply the components of emotional intelligence in Table 1 to Bem's (1981) Masculinity and Femininity Index, we find that it is linked clearly with skills and traits culturally associated with femininity. In this vein, Vecchio (2002) asserts that an inclusive style of leadership is most appropriate for value-adding and, indeed, may favor women leaders. This is entirely in opposition to most descriptions and characterizations of entrepreneurship.

\section{Leadership and Gender}

Within the leadership literature, there is inspection of styles of and approaches to effective leadership, and as demonstrated, such analyses include the identification of different skills as contributing to effectiveness. This includes the more tacit, culturally feminine skills (according to Bem's Index) but does not in fact reflect a less gendered paradigm. On the contrary, Koenig et al.'s (2011) meta-analysis of the literature on psychological constructs underpinning leadership has shown leadership to be construed as masculine, particularly among men. As noted, in Bem's Index (1981), the item "leadership" is also associated with masculinity. According to Due Billing and Alvesson (2000, p. 145), historically, the leadership literature has been prone to a masculinity norm which has become the "standard against which other categories are measured."

If buy-in from followers for entrepreneurial growth-based activity is best achieved by authentic transformational leadership, followers must believe in the authenticity of the vision, the activities required to achieve it, and the authenticity of the leader. However, according to Eagly (2005), authenticity requires legitimacy based on common values and identification with the leader. Thus, when leadership is conceptualized as a masculine role, this creates a challenge for women leaders in asserting authenticity. This is the central finding in the empirical study of Eagly, Makhijani, and Klonsky (1992) in which female leaders were valued significantly lower by followers compared with male leaders and that the ascription of that lower value was based on sex rather than performance or outcome. Entrepreneurship is likely to suffer the same problem since, as discussed, it is understood to be a male or masculinized role (Ogbor 2000). Certainly, Appelbaum, Audet, and Miller (2003) propose that other environmental factors, or social norms such as gender status beliefs, perpetuate the male norm or masculinization of both leadership and entrepreneurship (see also Ridgeway 2001). It is these core elements that both link leadership to entrepreneurship and, at the same time, challenge the heart of the entrepreneurship paradigm.

The lack of theoretical development in terms of entrepreneurship and leadership makes necessary a new approach to developing theoretical insight. Our understanding needs to develop beyond normative and gendered interpretations of both. Mirchandani (1999) calls for the use of feminist theory to guide this development (see also Hurley 1999). We propose that the feminist assertion of "performativity" in particular may be useful here. 


\section{Feminist Theory, \\ Performativity, and Entrepreneurial Leadership}

Contemporary feminist debates on gender have moved away from binary essentialist accounts of male and female. Rather, constructivist perspectives have allowed for analyses which aim to understand how gender is formed and reformed through everyday practices (Poggio 2006). West and Zimmerman (1987) developed Goffman's (1976) concept of Gender Display to consider "doing gender," specifically that gender should be viewed as particular activities that are appropriate for a person's sex category. This conceptualization was used by Gherardi (1994) to consider how the gender order is (re)produced within organizational contexts, with the continued valorization of the male/masculine. Butler (1990) has taken such analyses to undermine conceptualization of gender and to imagine other ways of being by proposing that gender is performative.

The concept of performativity predates the work of Butler who is most commonly associated with its use to understand gender, and it extends to considerations of the embodiment of contemporary work identities (McKinlay 2010). For Butler (1990), the act of performing "creates what it describes" (Poggio 2006, p. 226). It is important here to distinguish between performance, which implies conscious action, and performativity which reflects the compliance with norms while allowing for some resistance (McKinlay 2010). For Butler (1990), gender is formed through the repetition of these performances (Hodgson 2005).

Inspection of the academic literature reveals that modern theories of leadership are reasonably compatible with ideas about performativity. Just as feminist theory identifies that masculine and feminine are neither binary nor fixed, but performative, so too has the leadership literature moved away from understanding leaders as something that individuals are, and instead understands leadership as something that individuals do (e.g., Bergman et al. 2012; Nixon, Harrington, and Parker 2012). These ideas have been used to understand how leadership is not a property of the individual, rather how the doing of leadership and the performance of organizational norms in themselves construct leadership (Crevani, Lindgren, and Packendorff 2010). Such work has led to a fundamental ontological shift in our understanding of leader- ship. As noted earlier, in practice in many organizations, far from removing gendered interpretations, leadership is still understood to be exclusionary and masculinized in many contexts (Eagly 2005; Ford 2005), suggesting further work is required in this area. Despite this, understanding leadership as a performative activity does afford inspection and challenge; if performative activity is something that is done, then it can be undone (Butler 2004; Deutsch 2007) or redone (West and Zimmerman 2009).

In contrast to the advances in the ontological considerations of leadership, our understanding of entrepreneurship largely has not yet moved beyond "the entrepreneur" or the idea of entrepreneurship existing independently. However, within the literature on female entrepreneurship in particular, epistemological paradigms have questioned such "essential" characteristics. As already noted, Gartner (1989) introduced the idea of entrepreneurship as a process, and since then, there has been increasing engagement with the process notion of "entrepreneuring" (e.g., Ahl and Marlow 2012; Calás, Smircich, and Bourne 2009; Steyaert 2007). In this context, "the entrepreneur" is not an objective truth, but instead, "entrepreneuring" comprises actions and behaviors, subjective, but no less real for those experiencing them (Howarth, Tempest, and Coupland 2005). A consequence of this paradigm-changing perspective is that it requires methodologies appropriate to the study of social, subjective realities rather than a reliance on positivist ontologies and epistemologies (Calás, Smircich, and Bourne 2009; Campbell 2006). Nevertheless, despite a growing body of literature on women entrepreneurs, much of this literature has retained notions of the entrepreneur or entrepreneurship existing independently of the person doing it. Thus, we acknowledge the contribution of authors such as Petterson (2004) and Ahl and Marlow (2012) who have advocated feminist approaches to interpret entrepreneurship and gender in particular. To this end, Bruni, Gherardi, and Poggio (2004) posit that gender and entrepreneurship are enacted, rather than properties of the individual (though that enactment was found in their empirical study to be typically related to the masculine). We argue here that in a similar vein, if entrepreneurship is treated as synonymous, or even conceptually linked to, entrepreneurial leadership, it must be performative. The masculinized construct of entrepreneurial leadership is "performed" to a greater or lesser 
extent by individuals, as is entrepreneurship. Additionally, though, we argue that the extent to which entrepreneurship is understood as a masculine construct is overstated anyway since there appears to be much influence from leadership styles and features commonly associated with femininized cultural markers, notably emotion, and including support, relationships, and consideration, at least as features of emotional intelligence.

So what does this mean for studies of entrepreneurship and entrepreneurial leadership? The parallels of the traditional entrepreneurial "heroic male" with nature and the survival of the fittest have always been tempting, and indeed, the explicit link between entrepreneurship and "alpha males" is made in Nicholson (1998). But this masculinized paradigm is misleading in that it presents a very limited conceptualization of entrepreneurship. Any alternative to the idealized and masculine construction is rendered "other" categories of entrepreneurship, relegated as separate in the general analysis (Campbell 2004). Various authors have asserted that women's entrepreneurship is marginalized (e.g., Ahl and Marlow 2012; Bird and Brush 2002; Hamilton 2006); Galloway (2007) finds the same for alternative masculinities, such as those enacted by gay men. But even when entrepreneurship is defined as the pursuit or achievement of commercial growth, it requires both "masculine" and "feminine" skills, the latter of which seem to have been entirely ignored (or excluded) in the entrepreneurship literature (Bird and Brush 2002).

Supporting other work that seeks to move the research agenda away from an arbitrary, normative understanding of entrepreneurship, the concept of entrepreneuring and, we argue, the adoption of a performative framework allows for a fundamental ontological shift in what we understand entrepreneurial leadership to be. Just as gender is performative and constituted through repetition of social norms, entrepreneurial leadership can be seen, not as a property of the individual but as situated practice. Entrepreneuring and performativity allow us to see that the doing of entrepreneurial leadership in itself forms the concept. This allows the possibility of undoing (Butler 1990; Powell, Bagilhole, and Dainty 2009) or redoing (West and Zimmerman 2009) entrepreneurial leadership. Further, if entrepreneurial leadership requires skills most often culturally asso- ciated with femininity, then the masculinization of entrepreneurship is exposed as indefensible anyway; it contradicts how commercial growth via entrepreneurial leadership is actually achieved and that clearly implies a research agenda for the future.

In particular, the complexities of entrepreneurship and entrepreneurial leadership, and how their performance is gendered, need to be made more visible. Challenging idealized concepts will give voice to those currently marginalized in scholarship, leading to richer and more nuanced understandings of entrepreneurship, leadership, and entrepreneurial leadership. The emerging literature on the enactment of entrepreneurship engages with this (e.g., Anderson, El Harbi, and Brahem 2013) and is one of the avenues rich with potential for improving our understanding of entrepreneurship as it actually exists in the real world. Further, entrepreneurship research must challenge gender binaries and decouple the analyses which assume masculinity is performed by those with male bodies. Viewing entrepreneurial leadership through the feminist lens of performativity opens up avenues for innovative methodological approaches, beyond the conventional methods employed in the majority of research. Researchers could utilize visual methods, for example, semiotic analysis of the symbols of gendered entrepreneurial leadership. A further avenue for understanding the gendered enactment of entrepreneurship from a performative perspective could include the analysis of cultural artifacts. Previous organizational studies research has successfully analyzed cultural artifacts, such as artwork, to reveal the gendered lived experience of working lives (Hancock and Tyler 2007). More recently, researchers have used autobiographies of social entrepreneurs to understand the work life interface (Dempsey and Sanders 2010). Approaches which draw on the popular culture representations of working life, such as autobiographies, could offer rich detail on how the gendered enactment of entrepreneurship (entrepreneurial leadership) is both represented and created.

\section{Conclusions}

Entrepreneurship is identifiably masculinized as a construct within most of the extant entrepreneurship literature, with a focus on a particular form of masculinity. Modern theories of leadership are, by and large, not. In fact, 
leadership scholars increasingly acknowledge the requirement of attributes which are traditionally considered aligned with the performance of forms of femininity, such as emotional intelligence, seen as a prerequisite of effective leadership that fosters all the component parts of innovation, growth, and valueadding in organizations. We argue that the entrepreneurship literature seems to have much to learn from the scholarship and scrutiny applied in gender studies and in leadership studies in that it may be far more revelatory to understand entrepreneurship as a performative concept, rather than as an independent variable. Fundamentally, we reiterate the argument in previous studies that the reliance on masculinized interpretations of entrepreneurship is inappropriate and, in fact, limits knowledge of entrepreneurship theory and practice.

The contributions of this paper are twofold. First, there are implications for scholarship in that a revisioning of entrepreneurial leadership can be achieved through reference to feminist literature. This can help to shift the underlying ontologies and epistemologies used to understand the conceptualizations of entrepreneurship and entrepreneurial leadership. Second, this paper contributes to practice, by detailing the disconnect between entrepreneurship as a masculinized concept, and the requirements for effective leadership, including features marked culturally as feminized. We argue that the most successful entrepreneurs are likely to be highly adept at support, nurture, empathy, etc. In short, it may be the case that the most successful entrepreneurial leaders, rather than embodying the shrewd, ruthless businessman stereotype, may well be more "in touch with their feminine side" than they-or the entrepreneurship research community-care to admit. From a paradigmatic perspective, if studies of entrepreneurial leadership can move beyond ontologies that assume entrepreneurship and leadership to be properties of the individual, rather than situated practice, then a more nuanced understanding of the field may be reached. This paper seeks to contribute to knowledge and understanding of entrepreneurship, and entrepreneurial leadership in particular, by identifying a need for the research community to engage in studies that seek to investigate these activities as they occur in reality for those who create and develop value. We argue that normative approaches to studying entrepreneurship limit understanding and that inspection of entrepre- neurial leadership exposes normative interpretations of "the entrepreneur" as entirely idealized. As scholars, we have a duty to challenge this insofar as it does not represent the reality of entrepreneurship and, therefore, consistently denies us robust analysis.

\section{References}

Anderson, A., S. El Harbi, and M. Brahem (2013). "Enacting Entrepreneurship in 'Informal' Businesses," International Journal of Entrepreneurship and Innovation 14(3), 137-150.

Ahl, H. (2006). "Why Research on Women's Enterprise Needs New Direction," Entrepreneurship Theory and Practice 30(5), 595621.

Ahl, H., and S. Marlow (2012). "Exploring the Dynamics of Gender, Feminism and Entrepreneurship: Advancing Debate to Escape a Dead End?," Organization 19(5), 543-562.

Appelbaum, S. H., L. Audet, and J. C. Miller (2003). "Gender and Leadership? Leadership and Gender? A Journey Through the Landscape of Theories," Leadership E Organization Development Journal 24(1), 43-51.

Avolio, B. J. (1999). Full Leadership Development: Building the Vital Forces in Organizations. Thousand Oaks, CA: Sage.

Avolio, B. J., and B. M. Bass (2002). Developing Potential across a Full Range of Leadership: Cases on Transactional and Transformational Leadership. Mahwah, NJ: Lawrence Erlbaum.

Bass, B., and R. Riggio (2006). Transformational Leadership, 2nd ed. Mahwah, NJ: Lawrence Erlbaum.

Bass, B. M. (1998). Transformational Leadership: Industry, Military, and Educational Impact. Mahwah, NJ: Lawrence Erlbaum.

Bem, S. (1981). Bem Sex-Role Inventory. Palo Alto: Mind Garden.

Bergman, J. Z., J. R. Rentsch, E. E. Small, S. W. Davenport, and S. M. Bergman (2012). "The Shared Leadership Process in DecisionMaking Teams," The Journal of Social Psychology 152(1), 17-42.

Bird, B., and C. Brush (2002). "A Gendered Perspective on Organizational Creation," Entrepreneurship Theory and Practice 26(3), 41-65.

Blanchard, K. H., P. Zigarmi, and D. Zigarmi (1985). Leadership and the One Minute Manager: Increasing Effectiveness through Situational Leadership. New York: Morrow. 
Bruni, A., S. Gherardi, and B. Poggio (2004). "Doing Gender, Doing Entrepreneurship: An Ethnographic Account of Intertwined Practices," Gender, Work E Organization 11(4), 406-429.

Butler, J. (1990). Gender Trouble: Feminism and the Subversion of Identity. London: Routledge.

__ (2004). Undoing Gender. London: Routledge.

Calás, M. B., L. Smircich, and K. A. Bourne (2009). "Extending the Boundaries: Reframing 'Entrepreneurship as Social Change' Through Feminist Perspectives," Academy of Management Review 34(3), 552569.

Campbell, K. (2004). "Quilting a Feminist Map to Guide the Study of Women Entrepreneurs," in Narrative and Discursive Approaches in Entrepreneurship: A Second Movements in Entrepreneurship Book. Eds. D. Hjorth and C. Steyaert. Cheltenham: Edward Elgar Publishing, 194-209.

__ (2006). "Women, Mother Earth and the Business of Living," in Entrepreneurship as Social Change: A Third New Movements in Entrepreneurship Book. Eds. C. Steyaert and D. Hjorth. Cheltenham: Edward Elgar Publishing, 165-187.

Cardon, M. S., M. D. Foo, D. Shepherd, and J. Wiklund (2012). "Exploring the Heart: Entrepreneurial Emotion Is a Hot Topic," Entrepreneurship Theory and Practice 36(1), 1-10.

Crevani, L., M. Lindgren, and J. Packendorff (2010). "Leadership, Not Leaders: On the Study of Leadership as Practices and Interactions," Scandinavian Journal of Management 26(1), 77-86.

Dempsey, S. E., and M. L. Sanders (2010). "Meaningful Work? Nonprofit Marketization and Work/Life Imbalance in Popular Autobiographies of Social Entrepreneurship," Organization 17(4), 437-459.

Deutsch, F. M. (2007). "Undoing Gender," Gender \& Society 21(1), 106-127.

Díaz-García, M.-C., and F. Welter (2013). "Gender Identities and Practices: Interpreting Women Entrepreneurs' Narratives," International Small Business Journal 31(4), 384-404.

Drucker, P. (1986). Innovation and Entrepreneurship. New York: Harpercollins Publishers.

- (1995). Managing in a Time of Great Change. London: BCA.
Due Billing, Y., and M. Alvesson (2000). "Questioning the Notion of Feminine Leadership: A Critical Perspective on the Gender Labelling of Leadership," Gender, Work E Organization 7(3), 144-157.

Eagly, A. H. (2005). "Achieving Relational Authenticity in Leadership: Does Gender Matter?," the Leadership Quarterly 16(3), 459-474.

Eagly, A. H., M. G. Makhijani, and B. G. Klonsky (1992). "Gender and the Evaluation of Leaders: A Meta-Analysis," Psychological Bulletin 111(1), 3.

Fiedler, F. E. (1967). A Theory of Leadership Effectiveness. New York: McGraw-Hill.

Florida, R. (2003). "Entrepreneurship, Creativity and Regional Economic Growth," in The Emergence of Entrepreneurship Policy: Governance, Start-Ups and Growth in the Us Knowledge Economy. Ed. D. M. Hart. Cambridge: Cambridge University Press, 39-60.

Ford, J. (2005). "Examining Leadership Through Critical Feminist Readings," Journal of Health Organization and Management 19(3), 236-251.

Franco, M., and P. Matos (2013). "Leadership Styles in SMEs: A Mixed-Method Approach," International Entrepreneurship and Management Journal. Published online November 2013 at http://download-v2.springer .com/static/pdf/725.

Fris, C., C. Karlsson, and T. Paulsson (2005). "Relating Entrepreneurship to Economic Growth," in The Emerging Digital Economy: Entrepreneurship, Clusters and Policy. Eds. B. Johansson, C. Karlsson, and R. R. Stough. Berlin: Springer-Verlag, 83-112.

Galloway, L. (2007). "Entrepreneurship and the Gay Minority: Why the Silence?," International Journal of Entrepreneurship and Innovation 8(4), 271-280.

Gartner, W. B. (1989). "Who Is an Entrepreneur?' Is the Wrong Question," Entrepreneurship Theory and Practice 13(4), 47-67.

Geoghegan, L., and V. Dulewicz (2008). "Do Project Managers' Leadership Competencies Contribute to Project Success?," Project Management Journal 39(4), 58-67.

Gherardi, S. (1994). "The Gender We Think, the Gender We Do in Our Everyday Organizational Lives," Human Relations 47(6), 591610.

Goffman, E. (1976). "Gender Display," Studies in the Anthropology of Visual Communication 3, 69-77. 
Goleman, D. (1998). "What Makes a Leader?," Harvard Business Review 76(6), 93-103.

___ (2000). "Leadership That Gets Results," Harvard Business Review 78, 78-90.

Gupta, V., I. C. Macmillan, and G. Surie (2004). "Entrepreneurial Leadership: Developing and Measuring a Cross-Cultural Construct," Journal of Business Venturing 19, 241-260.

Hamilton, E. E. (2006). "Whose Story Is It Anyway? Narrative Accounts of the Role of Women in Founding and Establishing Family Businesses," International Small Business Journal 24(3), 253-271.

Hancock, P., and M. Tyler (2007). "Un/Doing Gender and the Aesthetics of Organizational Performance," Gender, Work \& Organization 14(6), 512-533.

Hodgson, D. (2005). "Putting on a Professional Performance: Performativity, Subversion and Project Management," Organization 12(1), 51-68.

Holt, C., and J. B. Ellis (1998). "Assessing the Current Validity of the Bem Sex-Role Inventory," Sex Roles 39(11-12), 929-941.

Howarth, C., S. Tempest, and C. Coupland (2005). "Rethinking Entrepreneurship Methodology and Definitions of the Entrepreneur," Journal of Small Business and Enterprise Development 12(1), 24-40.

Hurley, A. E. (1999). "Incorporating Feminist Theories Into Sociological Theories of Entrepreneurship," Women in Management Review 14(2), 54-62.

Koenig, A. M., A. H. Eagly, A. A. Mitchell, and T. Ristikari (2011). "Are Leader Stereotypes Masculine? A Meta-Analysis of Three Research Paradigms," Psychological Bulletin 137(4), 616.

Levie, J., and B. B. Lichtenstein (2010). "A Terminal Assessment of Stages Theory: Introducing a Dynamic States Approach to Entrepreneurship," Entrepreneurship Theory and Practice 34(2), 317-350.

McKinlay, A. (2010). "Performativity and the Politics of Identity: Putting Butler to Work," Critical Perspectives on Accounting 21(3), 232-242.

Mintzberg, H., B. Ahlstrand, and J. Lampel (1998). Strategy Safari. Harlow: Prentice Hall.

Mirchandani, K. (1999). "Feminist Insight on Gendered Work: New Directions in Research on Women and Entrepreneurship," Gender, Work \& Organization 6(4), 224235.
Moroz, P. W., and K. Hindle (2012). "Entrepreneurship as a Process: Toward Harmonizing Multiple Perspectives," Entrepreneurship Theory and Practice 36(4), 781-818.

Morris, M. H., M. N. Nola, W. E. Craig, and S. M. Coombes (2006). "The Dilemma of Growth: Understanding Venture Size Choices of Women Entrepreneurs," Journal of Small Business Management 44(2), 221-244.

Nicholson, N. (1998). "Personality and Entrepreneurial Leadership: A Study of the Heads of the UK's Most Successful Independent Companies," European Management Journal 16(5), 529-539.

Nixon, P., M. Harrington, and D. Parker (2012). "Leadership Performance Is Significant to Project Success or Failure: A Critical Analysis," International Journal of Productivity and Performance Management 61(2), 204216.

Nordqvist, M., and L. Melin (2010). "Entrepreneurial Families and Family Firms," Entrepreneurship \& Regional Development 22(34), 211-239.

Ogbor, J. O. (2000). "Mythicizing and Reification in Entrepreneurial Discourse: IdeologyCritique of Entrepreneurial Studies," Journal of Management Studies 37(5), 605-635.

Petterson, K. (2004). "Masculine Entrepreneurship-The Gnosjö Discourse in a Feminist Perspective," in Narrative and Discursive Approaches in Entrepreneurship. Eds. D. Hjorth and C. Steyaert. Cheltenham: Edward Elgar, 177-193.

Poggio, B. (2006). "Editorial: Outline of a Theory of Gender Practices," Gender, Work E Organization 13(3), 225-233.

Powell, A., B. Bagilhole, and A. Dainty (2009). "How Women Engineers Do and Undo Gender: Consequences for Gender Equality," Gender, Work \& Organization 16(4), 411428.

Ram, M., T. Abbas, B. Sanghera, and G. Hillin (2000). "Currying Favour with the Locals: Balti Owners and Business Enclaves," International Journal of Entrepreneurial Behaviour \& Research 6(1), 1355-2554.

Ridgeway, C. L. (2001). "Gender, Status, and Leadership," Journal of Social Issues 57(4), 637-655.

Ryan, R. M., and E. L. Deci (2003). "On Assimilating Identities to the Self: A SelfDetermination Theory Perspective on Internalization and Integrity Within Cultures," in Handbook of Self and Identity. Eds. M. R. 
Leary and J. P. Tangney. New York: Guilford, 225-246.

Salaman, G., and J. Storey (2002). "Managers' Theories About the Process of Innovation," Journal of Management Studies 39, 147165.

Sang, K. J., A. R. Dainty, and S. G. Ison (2014). "Gender in the UK Architectural Profession: (Re)Producing and Challenging Hegemonic Masculinity," Work, Employment and Society 28(2), 247-264. doi: 10.1177/ 0950017013491306.

Shamir, B., R. House, and M. Arthur (1993). "The Motivational Effects of Charismatic Leadership: A Self-Concept Based Theory," Organization Science 4(4), 577-594.

Smith, R., and D. Air (2012). "No Choices, No Chances! How Contemporary Enterprise Culture Is Failing Britain's Underclasses," International Journal of Entrepreneurship and Innovation 13(2), 103-113.

Steyaert, C. (2007). "'Entrepreneuring' As a Conceptual Attractor? A Review of Process
Theories in 20 Years of Entrepreneurship Studies," Entrepreneurship \& Regional Development 19(6), 453-477.

Thompson, J. L. (1999). "The World of the Entrepreneur-A New Perspective," Journal of Workplace Learning: Employee Counselling Today 11(6), 209-224.

Vecchio, R. P. (2002). "Leadership and Gender Advantage," The Leadership Quarterly 13(6), 643-671.

West, C., and D. H. Zimmerman (1987). "Doing Gender," Gender and Society 1(2), 125151.

—_ (2009). "Accounting for Doing Gender," Gender and Society 23(1), 112-122.

Williams, C. C., and S. J. Nadin (2013). "Beyond the Entrepreneur as a Heroic Figurehead of Capitalism: Re-Representing the Lived Practices of Entrepreneurs," Entrepreneurship $\mathcal{E}$ Regional Development 25(7-8), 552-568.

Xavier, S. R., D. Kelley, J. Kew, M. Herrington, and A. Vorderwülbecke (2013). "Gem 2012 Global Report.” http://gemconsortium.org. 